Article

\title{
Aspirin down Regulates Hepcidin by Inhibiting NF-KB and IL6/JAK2/STAT3 Pathways in BV-2 Microglial Cells Treated with Lipopolysaccharide
}

\author{
Wan-Ying Li ${ }^{1,2, \dagger}$, Fei-Mi Li ${ }^{1,+}$, Yu-Fu Zhou ${ }^{1}$, Zhong-Min Wen ${ }^{2, *}$, Juan Ma ${ }^{1,3}, \mathrm{Ke} \mathrm{Ya}^{3, *}$ \\ and Zhong-Ming Qian ${ }^{1, *}$ \\ 1 Laboratory of Neuropharmacology, Fudan University School of Pharmacy, Shanghai 201203, China; \\ 1j19840208@126.com (W.-Y.L.); 1fm19910916@sina.com (F.-M.L.); zyf19850722@126.com (Y.-F.Z.); \\ mj19890412@126.com (J.M.) \\ 2 Department of Neurology, The Second Affiliated Hospital of Soochow University, Suzhou 215004, China \\ 3 School of Biomedical Sciences, Faculty of Medicine, The Chinese University of Hong Kong, Shatin, NT, \\ Hong Kong, China \\ * Correspondence: sy19871104@yahoo.com (Z.-M.W.); yake@cuhk.edu.hk (K.Y.); \\ qianzhongming@fudan.edu.cn (Z.-M.Q.); Tel.: +86-21-5198-0178 (Z.-M.W. \& Z.-M.Q.); +852-3943-6780 (K.Y.) \\ + These authors contributed equally to this work. \\ Academic Editor: Juan M. Tomás \\ Received: 30 September 2016; Accepted: 9 November 2016; Published: 16 December 2016
}

\begin{abstract}
Aspirin down regulates transferrin receptor 1 (TfR1) and up regulates ferroportin 1 (Fpn1) and ferritin expression in BV-2 microglial cells treated without lipopolysaccharides (LPS), as well as down regulates hepcidin and interleukin 6 (IL-6) in cells treated with LPS. However, the relevant mechanisms are unknown. Here, we investigate the effects of aspirin on expression of hepcidin and iron regulatory protein 1 (IRP1), phosphorylation of Janus kinase 2 (JAK2), signal transducer and activator of transcription 3 (STAT3) and P65 (nuclear factor- $\mathrm{kB}$ ), and the production of nitric oxide (NO) in BV-2 microglial cells treated with and without LPS. We demonstrated that aspirin inhibited hepcidin mRNA as well as NO production in cells treated with LPS, but not in cells without LPS, suppresses IL-6, JAK2, STAT3, and P65 (nuclear factor-kB) phosphorylation and has no effect on IRP1 in cells treated with or without LPS. These findings provide evidence that aspirin down regulates hepcidin by inhibiting IL6/JAK2/STAT3 and P65 (nuclear factor-kB) pathways in the cells under inflammatory conditions, and imply that an aspirin-induced reduction in TfR 1 and an increase in ferritin are not associated with IRP1 and NO.
\end{abstract}

Keywords: aspirin; hepcidin; P65 (nuclear factor-kB); IL-6/JAK2/STAT3 pathway; lipopolysaccharide (LPS); nitric oxide (NO); iron regulatory protein 1 (IRP1)

\section{Introduction}

Aspirin is a non-steroidal anti-inflammatory drug (NSAID) and has been used for many years to treat a wide range of maladies, including pain and inflammation [1]. Preclinical and clinical studies have evidenced that aspirin has beneficial effects on mood disorders and schizophrenia and that high-dose aspirin is associated with a reduced risk of Alzheimer's disease (AD) [2]. This oldest agent in medicine has also been considered to be a potential new therapy for a range of neuropsychiatric disorders [2].

Studies have demonstrated that aspirin and sodium salicylate have a significant neuro-protective role in 1-methyl-4-phenyl-1,2,3,6-tetrahydropyridine (MPTP) [3,4], rotenone [5], 1-methyl-4-phenylpyridiniumion ( $\left.\mathrm{MPP}^{+}\right)$, and 6-hydroxydopamine (6-OHDA) [6] animal models in vivo and in neurons exposed to 6-OHDA and $\mathrm{MPP}^{+}$in vitro [7]. MPTP, rotenone, 6-OHDA, 
and $\mathrm{MPP}^{+}$are all neurotoxins known to trigger oxidative stress [4,7]. The neuro-protective effects of aspirin against oxidative stress induced by these neurotoxins have therefore been considered to be related to its ability to scavenger free radicals $[3,4,6]$.

Abnormally high levels of iron and oxidative stress have been observed in a number of neurodegenerative disorders [8-11]. Iron is a major generator of reactive oxygen species (ROS), and oxidative stress resulting from increased iron in the brain has been widely considered to be an initial causes of neuronal death in some neurodegenerative diseases [12,13]. In addition, it has been demonstrated that aspirin can affect iron metabolism by increasing ferritin synthesis in the cultured bovine pulmonary artery endothelial cells [14] and reducing serum ferritin (SF) in humans [15].

The well-established association of inflammatory and expression of iron regulatory hormone hepcidin [16,17], the anti-inflammatory character of aspirin [2], and the findings as discussed above prompted us to speculate that aspirin might have the ability to affect iron metabolism. Recently, we therefore investigated the effects of aspirin on the expression of three major iron metabolism proteins, transferrin receptor 1 (TfR1), ferroportin 1 (Fpn1), and ferritin, as well as hepcidin and interleukin 6 (IL-6) in BV-2 microglial cells. We found that aspirin significantly down regulates TfR1 and up regulates Fpn1 and ferritin expressions in cells treated without lipopolysaccharides (LPS) in vitro, as well as down regulates hepcidin and IL-6 levels in cells treated with LPS [18]. However, the relevant mechanisms are unknown. In the present study, we investigate the effects of aspirin on expression of hepcidin mRNA and regulating molecules of hepcidin, including IL-6 mRNA, iron regulatory protein 1 (IRP1) protein, phosphorylation of Janus kinase 2 (JAK2), signal transducer and activator of transcription 3 (STAT3), P65 (nuclear factor- $\mathrm{kB}, \mathrm{NF}-\mathrm{kB}$ ), and nitric oxide (NO) in BV-2 microglial cells treated with and without LPS.

\section{Results}

\subsection{Aspirin Protects BV-2 Microglial Cells from Lipopolysaccharides (LPS)-Induced Damage}

We first investigated the effects of aspirin (ASA) on the cell viability by treating BV-2 microglial cells with a vehicle ( $0.1 \%$ ethanol) for $24 \mathrm{~h}$ (The Control), $0.1 \mathrm{mM}$ aspirin for $24 \mathrm{~h}$ (ASA), $0.1 \%$ ethanol for $18 \mathrm{~h}+1 \mu \mathrm{g} / \mathrm{mL}$ of LPS for $6 \mathrm{~h}$ (LPS), or aspirin for $18 \mathrm{~h}+1 \mu \mathrm{g} / \mathrm{mL}$ of LPS for $6 \mathrm{~h}$ (LPS + 0.1 mM ASA). We used $0.1 \mathrm{mM}$ aspirin because this concentration was found to have a significant effect on hepcidin mRNA expression in LPS-treated BV-2 microglial cells in another recent study [18]. The 3-(4,5-dimethylthiazol-2-yl)-2,5-diphenyltetrazolium bromide (MTT) assay showed that there was no significant difference in cell viability between cells treated with the vehicle (control) or with $0.1 \mathrm{mM}$ aspirin (Figure 1). It was also found that the cell viability in cells treated with LPS alone were significantly lower than those in the cells treated with the vehicle or the $0.1 \mathrm{mM}$ aspirin, implying that LPS could induce cell-damage under our in vitro experimental conditions. However, the viability of the cells treated with $0.1 \mathrm{mM}$ aspirin plus LPS was significantly higher than that of the cells treated with LPS alone and almost the same as that of control cells (Figure 1). This result is consistent with our recent findings [18] and re-confirmed that aspirin has a role in protecting BV-2 microglial cells from LPS-induced damage in vitro.

\subsection{Aspirin Inhibits Hepcidin mRNA Expression But Has No Effect on IRP1 Protein Expression in BV-2 Microglial Cells Treated with LPS}

We then investigated the effects of aspirin on hepcidin mRNA and IRP1 protein expression in BV-2 microglial cells by treating with a vehicle ( $0.1 \%$ ethanol) for $24 \mathrm{~h}$ (The Control), $0.1 \mathrm{mM}$ aspirin for $24 \mathrm{~h}$ (ASA), $0.1 \%$ ethanol for $18 \mathrm{~h}+1 \mu \mathrm{g} / \mathrm{mL}$ of LPS for $6 \mathrm{~h}$ (LPS), or aspirin for $18 \mathrm{~h}+1 \mu \mathrm{g} / \mathrm{mL}$ of LPS for $6 \mathrm{~h}$ (LPS + $0.1 \mathrm{mM}$ ASA). Treatment with LPS induced a significant increase in hepcidin mRNA expression, the levels of hepcidin mRNA in the cells treated with LPS being markedly higher than those in the controls (Figure 2A). However, hepcidin mRNA expression in the cells treated with aspirin plus LPS was significantly lower than that in the cells treated with LPS only, but there was 
no difference between the cells treated with aspirin or with the vehicle. These results demonstrated that aspirin could inhibit hepcidin mRNA expression in BV-2 microglial cells treated with LPS but not in the cells treated without LPS. Western blot analysis showed that there were no differences in IRP1 protein content between cells treated with aspirin or the vehicle, or with LPS or aspirin plus LPS (Figure 2B), evidencing that aspirin has no effect on IRP1 protein expression in BV-2 microglial cells treated with or without LPS.

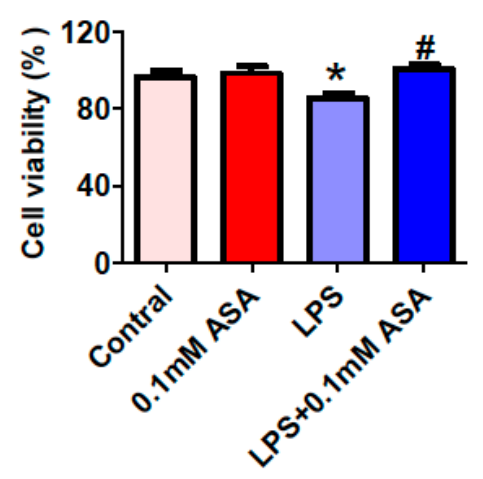

Figure 1. Aspirin protects BV-2 microglial cells from LPS-induced damage. BV-2 microglial cells were treated with $0.1 \%$ ethanol (Control) or aspirin (ASA) for $24 \mathrm{~h}-0.1 \%$ ethanol for $18 \mathrm{~h}$ and then $1 \mu \mathrm{g} / \mathrm{mL}$ of LPS for another $6 \mathrm{~h}$ (LPS) or aspirin for $18 \mathrm{~h}$ and then $1 \mu \mathrm{g} / \mathrm{mL}$ of LPS for another $6 \mathrm{~h}$ (LPS + $0.1 \mathrm{mM}$ ASA). Cell viability was then conducted as described in Materials and Methods. Data were represented as means $\pm \operatorname{SEM}(n=4)$. ${ }^{*} p<0.05$ vs. the control; $\# p<0.05$ vs. the LPS-treated group.

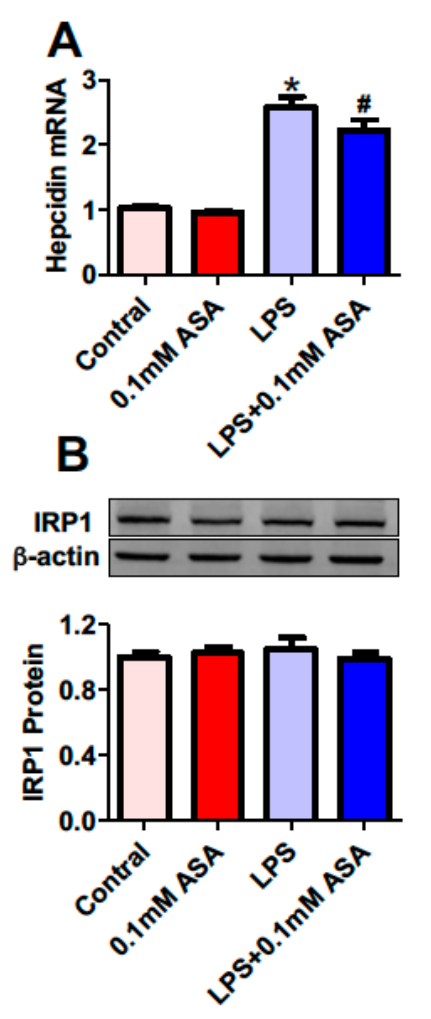

Figure 2. Aspirin inhibits hepcidin mRNA expression but has no effect on IRP1 protein expression in BV-2 microglial cells treated with LPS. BV-2 microglial cells were treated with $0.1 \%$ ethanol (Control) or aspirin (ASA) for $24 \mathrm{~h}-0.1 \%$ ethanol for $18 \mathrm{~h}$ and then $1 \mu \mathrm{g} / \mathrm{mL}$ of LPS for another $6 \mathrm{~h}$ (LPS) or aspirin for $18 \mathrm{~h}$ and then $1 \mu \mathrm{g} / \mathrm{mL}$ of LPS for another $6 \mathrm{~h}$ (LPS + 0.1 mM ASA). Expression of hepcidin mRNA (A) and IRP1 protein (B) were measured by RT-PCR and Western blot analysis, respectively. Data were presented as mean $\pm \operatorname{SEM}(n=5) .{ }^{*} p<0.05$ vs. the control; $\# p<0.05$ vs. the LPS-treated group. 
2.3. Aspirin Inhibits Phosphorylation of JAK2, STAT3, and P65(NF- $\kappa B$ ) and Expression of IL-6 mRNA in BV-2 Microglial Cells Treated with or without LPS

To understand why aspirin could inhibit hepcidin expression under inflammatory conditions, we investigated the effects of aspirin on phosphorylation of JAK2, STAT3, and P65 by incubating BV-2 microglial cells with a vehicle ( $0.1 \%$ ethanol) for $24 \mathrm{~h}$ (The Control), $0.1 \mathrm{mM}$ aspirin for $24 \mathrm{~h}$ (ASA), $0.1 \%$ ethanol for $18 \mathrm{~h}+1 \mu \mathrm{g} / \mathrm{mL}$ of LPS for $6 \mathrm{~h}$ (LPS), or aspirin for $18 \mathrm{~h}+1 \mu \mathrm{g} / \mathrm{mL}$ of LPS for $6 \mathrm{~h}$ (LPS + 0.1 mM ASA). It was found that the contents of p-JAK2 (Figure 3A), p-STAT3 (Figure 3B), p-P65 (Figure 3C), and IL-6 mRNA (Figure 4A) in the cells treated with LPS were significantly higher than those in the control cells as well as in the cells treated with aspirin plus LPS. This implied that LPS could dramatically increase JAK2, STAT3, and P65(NF- $\mathrm{kB}$ ) phosphorylation and IL-6 mRNA expression, while aspirin was able to attenuate the LPS-induced increase in phosphorylation and expression. In addition, our findings showed that the levels of IL-6, p-JAK2, p-STAT3, and p-P65(NF-KB) in the cells treated with aspirin only were significantly lower than those in the control cells, suggesting that aspirin was able to inhibit IL-6 mRNA expression, JAK2, STAT3, and P65(NF- $\mathrm{kB}$ ) phosphorylation under 'normal' conditions in vitro, not only under inflammatory conditions in vitro.
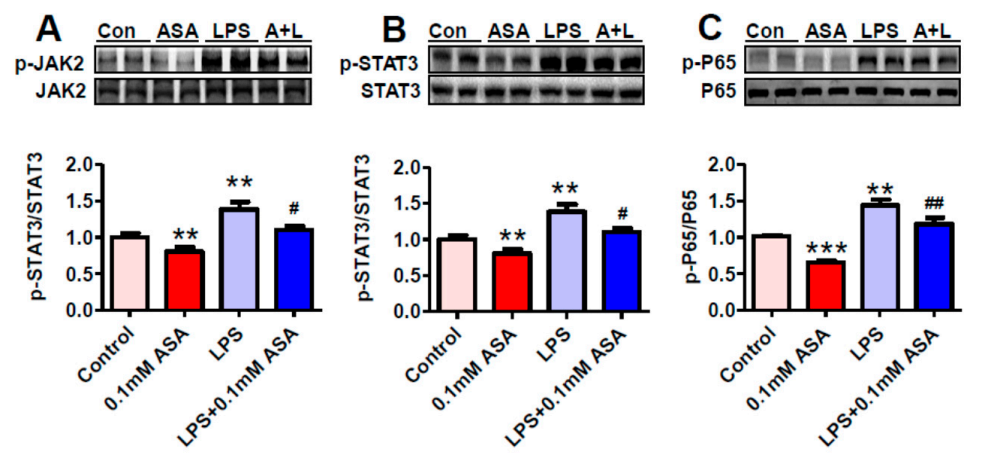

Figure 3. Aspirin inhibits phosphorylation of JAK2, STAT3, and P65(NF- $\mathrm{BB}$ ) in BV-2 microglial cells treated with or without LPS. BV-2 microglial cells were treated with $0.1 \%$ ethanol (Control) or aspirin (ASA) for $24 \mathrm{~h}-0.1 \%$ ethanol for $18 \mathrm{~h}$ and then $1 \mu \mathrm{g} / \mathrm{mL}$ of LPS for another $6 \mathrm{~h}$ (LPS) or aspirin for $18 \mathrm{~h}$ and then $1 \mu \mathrm{g} / \mathrm{mL}$ of LPS for another $6 \mathrm{~h}$ (LPS + $0.1 \mathrm{mM}$ ASA). Phosphorylation of JAK2 (A); STAT3 (B); and P65(NF-kB) (C) was detected by Western blot analysis, as described in Materials and Methods. Data were represented as mean \pm SEM $(n=5)$. ${ }^{* *} p<0.01 ;{ }^{* * *} p<0.001$ vs. the control; $\# p<0.05 ; \# \#<0.01$ vs. the LPS-treated group.
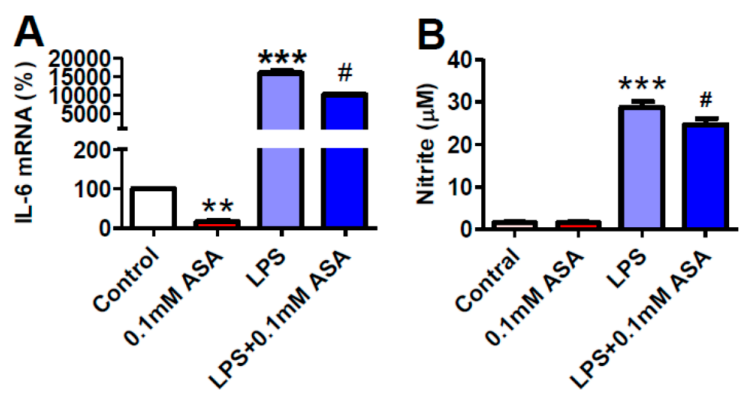

Figure 4. Aspirin inhibits expression of IL-6 mRNA in BV-2 microglial cells treated with or without LPS and NO production in BV-2 microglial cells treated with LPS but not in the cell treated without LPS. BV-2 microglial cells were treated with $0.1 \%$ ethanol (Control) or aspirin (ASA) for $24 \mathrm{~h}-0.1 \%$ ethanol for $18 \mathrm{~h}$ and then $1 \mu \mathrm{g} / \mathrm{mL}$ of LPS for another $6 \mathrm{~h}$ (LPS) or aspirin for $18 \mathrm{~h}$ and then $1 \mu \mathrm{g} / \mathrm{mL}$ of LPS for another $6 \mathrm{~h}$ (LPS + $0.1 \mathrm{mM}$ ASA). Expression of IL- 6 mRNA (A) was measured by RT-PCR and production of NO (B) was assayed by measuring the levels of nitrite (a metabolite of NO) in culture medium as described in Materials and Methods. Data were represented as mean $\pm \operatorname{SEM}(n=5)$. ** $p<0.01 ;{ }^{* * *} p<0.001$ vs. the control; \# $p<0.05$ vs. the LPS-treated group. 


\subsection{Aspirin Inhibits NO Production in BV-2 Microglial Cells Treated with LPS But Not in the Cell Treated without LPS}

In a previous study, we demonstrated that aspirin down regulates TfR 1 and up regulates Fpn 1 and ferritin expression in BV-2 microglial cells in vitro; however, the mechanisms are unknown. It has been documented that NO can regulate the expression of TfR1 and ferritin by interacting with IRP1 [19-21]. To find out whether NO is involved in the effects of ASA on TfR1 and ferritin expression, we also investigated the effects of ASA on NO production in the cells treated with or without LPS. Treatment with LPS was found to induce a significant increase in NO levels, while pre-treatment with ASA displayed a marked inhibition on the LPS-induced increase in NO production, the levels of NO being significantly lower in ASA + LPS-treated cells than in LPS-treated cells (Figure 4B). There were no differences in NO content between the ASA-treated and the control cells.

\section{Discussion}

It has been well-demonstrated that LPS is able to up regulate hepcidin expression [22] via the IL-6/STAT3 signaling pathway and then down regulate expression of TfR1 and Fpn1 in the brain [23]. In our recent study, we [18] demonstrated that aspirin significantly inhibits the LPS-induced increase in IL-6 and hepcidin mRNA expression and revises the LPS-evoked reduction in TfR1 and Fpn1 expression in BV-2 microglial cells. The inhibition of aspirin on IL- 6 and hepcidin mRNA expression suggests that aspirin might have play a role in suppressing the activated IL-6/ JAK2/STAT3 signaling pathway in LPS-treated BV-2 microglial cells. To test this hypothesis, we investigated the effects of aspirin on the contents of IL-6 mRNA, p-JAK2, and p-STAT3 in LPS-treated BV-2 microglial cells. We demonstrated that the significant increase in expression of IL-6 mRNA as well as phosphorylation of JAK2 and STAT3 induced by LPS could be largely suppressed by pre-incubation of the cells with aspirin. These findings provide evidence that aspirin down regulates hepcidin at least partly by inhibiting the IL6/JAK2/STAT3 pathway and then alleviates the LPS-induced reduction in TfR1 and Fpn1 expression in LPS-treated BV-2 microglial cells.

The transcription factor NF- $\mathrm{kB}$ is critical for the inducible expression of multiple cellular and viral genes involved in inflammation and infection including IL-6 [24,25]. Studies have demonstrated that aspirin and its metabolite sodium salicylate (another anti-inflammatory drug) are both able to

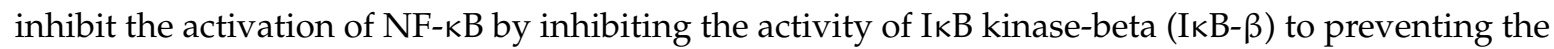
translocation of NF- $\mathrm{kB}$ to the nucleus $[24,26,27]$. Evidence also shows that the toll-like receptor 4 (TLR4) recognition of LPS (TLR4 ligand), a pathogen-associated molecular pattern, results in the triggering of downstream signaling cascades leading to the activation of NF- $k B$ [25]. These led us to speculate that the activation of NF- $\mathrm{KB}$ might play a role in the LPS-induced increase in hepcidin mRNA expression, while the inhibition of aspirin on hepcidin mRNA expression might be partly associated with its role in inhibiting the activation of NF- $\mathrm{NB}$, as has been found in human peripheral blood leukocytes [28]. We therefore investigated the effects of aspirin on P65(NF- $\mathrm{kB}$ ) phosphorylation in BV-2 microglial cells treated with LPS. P65(NF- $k B$ ) was examined here because the RelA(p65)-p50 heterodimer is the most frequently activated form of NF-KB in TLR signaling [29]. Our findings show that LPS can induce a marked increase in phosphorylation of P65(NF-kB), which can be significantly suppressed by the pre-incubation of cells with aspirin. This implies that the down regulation of hepcidin might also be partly associated with the inhibiting role of aspirin on NF- $\mathrm{kB}$ phosphorylation in LPS-treated BV-2 microglial cells.

It was noticed that aspirin was able to inhibit levels of phosphorylation of JAK2, STAT3, and P65(NF-kB) not only under in vitro inflammatory conditions but also in vitro 'normal' conditions. The levels of p-JAK2, p-STAT3, and p-P65 were found to be significantly lower in cells treated with ASA than those in the control cells. In theory, this could lead to a reduction in hepcidin mRNA in cells treated with ASA only. However, no difference was found in the contents of hepcidin mRNA between the cells treated with ASA and control cells. Under in vitro 'normal' conditions, the base-line level of JAK2, STAT3, and P65 is relatively lower, as compared with in vitro inflammatory conditions. 
Although aspirin can induce a reduction in the content of these mediators, the reduction might not be enough to result in significant changes in hepcidin mRNA expression. This is probably one of causes for the inconformity in the response of mediators and hepcidin to aspirin. Further studies on this possibility and other relevant causes are needed.

In a previous study, we demonstrated that aspirin down regulates TfR1 and up regulates Fpn1 and ferritin expression in BV-2 microglial cells treated without LPS [16]; however, the mechanisms are unknown. The responses of TfR1, Fpn1, and ferritin to aspirin are absolutely unrelated to hepcidin because the peptide has no response to aspirin under in vitro "normal" conditions. Like hepcidin, IRP1 is a key protein involved in the regulation of iron homeostasis. In most types of cells, the coordinated control of TfR1 and ferritin by cellular iron is mediated by IRP1 [30,31]. In addition, it has been documented that NO regulates expression of TfR1 and ferritin by interacting with IRP1 [19-21]. To find out why aspirin is able to down regulate TfR1 and up regulate Fpn1 and ferritin expression in BV-2 microglial cells under in vitro "normal" conditions, we examined the effects of aspirin on IRP1 expression and NO production in BV-2 microglial cells. We found that the levels of IRP1 as well as the NO in the cells treated with aspirin are no significantly different from those in the control cells. This finding implies that an aspirin-induced reduction in TfR 1 and an increase in ferritin are not associated with IRP1 and NO and suggest that there might be some unknown mechanism by which aspirin regulates TfR1 and ferritin expression under in vitro "normal" conditions.

Aspirin inhibits inflammation mainly through its ability to suppress cyclooxygenase (COX) activity [32]. There are two isoforms of this enzyme-COX1 and COX2 [33]. COX-1 is constitutively expressed in most tissues and produces prostanoids responsible for normal physiological functions. COX-2 is sparsely present in most healthy tissues [33] and functions as a key enzyme for prostaglandin biosynthesis. In addition, COX-2 has been shown to contribute to the LPS-induced inflammatory process $[34,35]$. Cellular responses to inflammatory stimuli, including LPS, mainly involve the activation of mitogen-activated protein kinase (MAPK) signaling cascades [36-38]. The p38MAPK and JNK subfamilies play critical roles in regulating expression of pro-inflammatory mediators such as COX-2 and interleukins such as IL-6 [39-42]. These data imply that aspirin should be able to inhibit a LPS-induced increase in COX2 expression in BV-2 microglial cells, probably via inhibiting MAPK/JNK pathway, although the content of COX2 was not measured in this study. In addition, we found that the tendency in the effect of aspirin, LPS, or both on IL-6, JAK2, and P65 is very similar to that on COX2 reported by others [34]. This might suggest that COX2 may play a role in the down regulation of hepcidin induced by aspirin in LPS-treated BV-2 microglial cells. Further studies on this possibility are needed.

\section{Materials and Methods}

\subsection{Chemicals}

Unless otherwise stated, all chemicals, including aspirin (ASA), LPS (Escherichia coli 055:B5), MTT (3-(4,5-dimethylthiazol-2-yl)-2,5-diphenyltetrazolium bromide), and mouse monoclonal anti- $\beta$-actin, were obtained from Sigma Chemical Co., St. Louis, MO, USA. A BCA protein assay kit and a Revert Aid First Strand cDNA Synthesis Kit were purchased from Thermo Scientific, Waltham, MA, USA, and TRIZOL Reagent from Life technologies, Carlsbad, CA, USA. Rabbit monoclonal anti-phospho-JAK2, rabbit monoclonal anti-JAK2, rabbit polyclonal anti-phospho-STAT3, mouse monoclonal anti-STAT3, rabbit monoclonal anti-phospho-P65, and rabbit monoclonal anti-P65 antibodies were supplied by Cell Signaling Technology, Inc., Danvers, MA, USA, and mouse monoclonal anti-IRP1 was from Abcam, San Francisco, CA, USA. Goat anti-rabbit and anti-mouse IRDye 800CW secondary antibodies were bought from LI-COR bio sciences, Lincoln, NE, USA. The Health Department of Hong Kong and Shanghai Government and the Animal Research Ethics Committee of The Chinese University of Hong Kong (the project identification code: GRF14106914, 1 January 2015) and Fudan University 
(the project identification code: NSFC31271132, 1 January 2013; NSFC31330035, 1 January 2014) approved the experimental procedures of this study.

\subsection{BV-2 Microglia Cells}

BV-2 microglia cells (a murine microglia cell line) were grown in a 5\% $\mathrm{CO}_{2}$ incubator at $37^{\circ} \mathrm{C}$ in Dulbecco's modified Eagle's medium (DMEM) supplemented with 10\% FBS (PAN Biotech, Aidenbach Bavaria, Germany) and antibiotics (penicillin $100 \mathrm{U} / \mathrm{mL}$, streptomycin $100 \mathrm{mg} / \mathrm{mL}$ ), and culture medium was changed every 2 days [24]. Then, BV-2 cells were seeded in 96-well plates $\left(6 \times 10^{3}\right.$ cells /well $)$ for cell viability assay, and 6-well plates $\left(4 \times 10^{5}\right.$ cells /well $)$ for RT-PCR and $\left(8 \times 10^{5}\right.$ cells/well) for Western blotting analysis [18]. The cells were treated with different concentrations of $0.1 \mathrm{mM}$ aspirin (in $0.1 \%$ ethanol) and/or LPS $(1 \mathrm{mg} / \mathrm{mL}$ in PBS), which were dissolved in fresh DMEM without serum.

\subsection{Assessment of Cell Viability}

The cell viability were measured using an MTT assay as described previously [43]. Briefly, a total of $25 \mu \mathrm{L}$ of MTT ( $1 \mathrm{~g} / \mathrm{L}$ in PBS) was added to each well before the conduction of incubation at $37^{\circ} \mathrm{C}$ for $4 \mathrm{~h}$. The assay was stopped by the addition of a $100 \mu \mathrm{L}$ of lysis buffer (20\% SDS in $50 \%$ $\mathrm{N}^{\prime} \mathrm{N}$-dimethylformamide, $\mathrm{pH}$ 4.7). Optical density (OD) was measured at the $570 \mathrm{~nm}$ wavelength by the use of an ELX-800 microplate assay reader (Bio-tek, Winooski, VT, USA), and the results were expressed as a percentage of absorbance measured in the control cells.

\subsection{NO Production Assay}

Production of NO was assayed by measuring the levels of nitrite (a metabolite of NO) in the culture medium using a colorimetric assay with Griess reagent according to Kim et al. [44], After $24 \mathrm{~h}$ of treatment with LPS with or without ASA, the culture media were collected and reacted with an equal volume of Griess reagent in 96-well culture plates and were incubated at room temperature for $10 \mathrm{~min}$ in the dark. The absorbance was measured at $540 \mathrm{~nm}$ using a microplate reader, and nitrite concentrations were calculated by reference to a standard curve generated by known concentrations of sodium nitrite.

\subsection{Quantitative Real-Time PCR}

Extraction of total RNA and preparation of cDNA were performed using a TRIZOL reagent andreverse transcription kit (Thermo Scientific) in accordance with the instruction of the manufacturers, respectively. The specific primers used for PCR are as follows: hepcidin forward, 5'-GAAGGCAAGATGGCACTAAGCA-3'; hepcidin reverse, 5'-TCTCGTCTGTTGCCGGAGATAG-3'; IL-6 forward, 5'-GAGGATACCACTCCCAACAGACC-3'; IL-6 reverse, 5'-AAGTGCATCATCGT TGTTCATACA-3'; $\beta$-actin forward, 5'-AAATCGTGCGTGACATCAAAGA-3'; $\beta$-actin reverse, 5'-GCCATCTCCTGCTCGAAGTC-3' [19,45]. Quantitative real-time PCR was conducted with CFX96 PCR instrument (Bio-Rad, Hercules, CA, USA) using specific primers and SYBR Premix II kit (Takara, Dalian, China). The $C_{t}$ values of each target gene were normalized to that of the $\beta$-actin mRNA. Relative gene expression was calculated by the $2^{-\Delta \Delta C t}$ method [46].

\subsection{Western Blot Analysis}

The cells were washed and lysed as described previously [47,48]. After centrifugation at $13,200 \times g$ for $15 \mathrm{~min}$ at $4{ }^{\circ} \mathrm{C}$, the supernatant was collected, and protein content was determined using the BCA protein assay kit. Aliquots of the extract containing about $20 \mu \mathrm{g}$ of protein were loaded and run on a single track of $10 \%$ SDS-PAGE under reducing conditions and subsequently transferred to a pure nitrocellulose membrane (Bio-Rad, Hercules, CA, USA). The blots were blocked and then incubated with primary antibodies—rabbit monoclonal anti-phospho-JAK2 (1:1000), rabbit monoclonal anti-JAK2 
(1:1000), rabbit polyclonal anti-phospho-STAT3 (1:1000), mouse monoclonal anti-STAT3 (1:1000), rabbit monoclonal anti-phospho-P65 (1:1000), rabbit monoclonal anti-P65 (1:1000), and mouse monoclonal anti-IRP1 (1:1000) antibodies-overnight at $4{ }^{\circ} \mathrm{C}$. After the incubation, the blots were washed three times and then incubated with goat anti-rabbit (1:1000) or anti-mouse IRDye $800 \mathrm{CW}$ secondary antibodies (1:5000) for $2 \mathrm{~h}$ at room temperature. The intensity of the specific bands was detected and analyzed by the Odyssey infrared image system (Li-Cor, Lincoln, NE, USA). To ensure even loading of the samples, the same membrane was probed with a mouse monoclonal anti- $\beta$-actin antibody at a 1:5000 dilution.

\subsection{Statistical Analysis}

Statistical analyses were performed using Graphpad Prism. Data were presented as mean \pm SEM. The differences between the means were all determined by a two-way analysis of variance (ANOVA). A probability value of $p<0.05$ was considered statistically significant.

\section{Conclusions}

We demonstrated that aspirin inhibits hepcidin mRNA as well as NO production in cells treated with LPS, but not in cells without LPS, suppresses IL-6, JAK2, STAT3, and P65(NF-kB) phosphorylation, and has no effect on IRP1 protein in cells treated with or without LPS. The findings provided evidence that aspirin down regulates hepcidin by inhibiting IL6/JAK2/STAT3 as well as P65(NF-kB) pathways in cells under inflammatory conditions and implies that an aspirin-induced reduction in TfR1 and an increase in ferritin were not associated with IRP1 and NO.

Acknowledgments: We thank Christopher Qian for his assistance with preparation and English revision of the manuscript. The studies in our laboratories were supported by the National Natural Science Foundation of China (31330035, 31271132, 31371092; 31571195), the Competitive Earmarked Grants of The Hong Kong Research Grants Council (GRF14106914, GRF14111815), and the Hong Kong Health and Medical Research Fund (01120146).

Author Contributions: Ke Ya and Zhong-Ming Qian conceived, organized, and supervised the study; Wan-Ying Li, Fei-Mi Li, Yu-Fu Zhou, and Juan Ma performed the experiments; Zhong-Min Wen contributed to the analysis of data; Ke Ya and Zhong-Ming Qian prepared, wrote, and revised the manuscript.

Conflicts of Interest: The authors declare no conflict of interest.

\section{Abbreviations}

$\begin{array}{ll}\text { ASA } & \text { aspirin } \\ \text { Fpn1 } & \text { ferroportin 1 } \\ \text { IL-6 } & \text { interleukin 6 } \\ \text { IRP1 } & \text { iron regulatory protein 1 } \\ \text { JAK2 } & \text { Janus kinase 2 } \\ \text { LPS } & \text { lipopolysaccharides } \\ \text { NO } & \text { nitric oxide } \\ \text { NSAID } & \text { non-steroidal anti-inflammatory drug } \\ \text { P65(NF-kB) } & \text { rela (p65) nuclear factor- } \mathrm{kB} \\ \text { SF } & \text { serum ferritin } \\ \text { STAT3 } & \text { signal transducer and activator of transcription 3 } \\ \text { TfR1 } & \text { transferrin receptor 1 }\end{array}$

\section{References}

1. Mulvihill, M.M.; Nomura, D.K. Therapeutic potential of monoacylglycerol lipase inhibitors. Life Sci. 2013, 92, 492-497. [CrossRef] [PubMed]

2. Berk, M.; Dean, O.; Drexhage, H.; McNeil, J.J.; Moylan, S.; O'Neil, A.; Sanna, L.; Maes, M. Aspirin: A review of its neurobiological properties and therapeutic potential for mental illness. BMC Med. 2013, 11, 74. [CrossRef] [PubMed]

3. Aubin, N.; Curet, O.; Deffois, A.; Carter, C. Aspirin and salicylate protect against MPTP-induced dopamine depletion in mice. J. Neurochem. 1998, 71, 1635-1642. [CrossRef] [PubMed] 
4. Mohanakumar, K.P.; Muralikrishnan, D.; Thomas, B. Neuroprotection by sodium salicylate against 1-methyl-4-phenyl-1,2,3, 6-tetrahydropyridine-induced neurotoxicity. Brain Res. 2000, 864, $281-290$. [CrossRef]

5. Madathil, S.K.; Karuppagounder, S.S.; Mohanakumar, K.P. Sodium salicylate protects against rotenone-induced Parkinsonism in rats. Synapse 2013, 67, 502-514. [CrossRef] [PubMed]

6. Di Matteo, V.; Pierucci, M.; di Giovanni, G.; di Santo, A.; Poggi, A.; Benigno, A.; Esposito, E. Aspirin protects striatal dopaminergic neurons from neurotoxin-induced degeneration: An in vivo microdialysis study. Brain Res. 2006, 1095, 167-177. [CrossRef] [PubMed]

7. Carrasco, E.; Werner, P. Selective destruction of dopaminergic neurons by low concentrations of 6-OHDA and $\mathrm{MPP}^{+}$: Protection by acetylsalicylic acid aspirin. Parkinsonism Relat. Disord. 2002, 8, 407-411. [CrossRef]

8. Riederer, P.; Dirr, A.; Goetz, E.; Sofic, E.; Jellinger, K.; Youdim, M.B.H. Distribution of iron in different regions and subcellular compartments in Parkinson's disease. Ann. Neurol. 1992, 32, s101-s104. [CrossRef] [PubMed]

9. Jenner, P. Oxidative damage in neurodegenerative disease. Lancet 1994, 344, 796-798. [CrossRef]

10. Gorell, J.M.; Ordidge, R.J.; Brown, G.G.; Deniau, J.C.; Buderer, N.M.; Helpern, J.A. Increased iron-related MRI contrast in the substantianigra in Parkinson's disease. Neurology 1995, 45, 1138-1143. [CrossRef] [PubMed]

11. Qian, Z.M.; Wang, Q. Expression of iron transport proteins and excessive iron accumulation in the brain in neurodegenerative disorders. Brain Res. Rev. 1998, 27, 257-267. [CrossRef]

12. Ke, Y.; Qian, Z.M. Iron misregulation in the brain: A primary cause of neurodegenerative disorders. Lancet Neurol. 2003, 2, 246-253. [CrossRef]

13. Ke, Y.; Qian, Z.M. Brain iron metabolism: Neurobiology and neurochemistry. Prog. Neurobiol. 2007, 83, 149-173. [CrossRef] [PubMed]

14. Oberle, S.; Polte, T.; Abate, A.; Podhaisky, H.P.; Schröder, H. Aspirin increases ferritin synthesis in endothelial cells: A novel antioxidant pathway. Circ. Res. 1998, 82, 1016-1020. [CrossRef] [PubMed]

15. Fleming, D.J.; Jacques, P.F.; Massaro, J.M.; D’Agostino, R.B., Sr.; Wilson, P.W.; Wood, R.J. Aspirin intake and the use of serum ferritin as a measure of iron status. Am. J. Clin. Nutr. 2001, 74, 219-226. [PubMed]

16. Pietrangelo, A.; Dierssen, U.; Valli, L.; Garuti, C.; Rump, A.; Corradini, E.; Ernst, M.; Klein, C.; Trautwein, C. STAT3 Is required for IL-6-gp130-dependent activation of hepcidin in vivo. Gastroenterology 2007, 132, 294-300. [CrossRef] [PubMed]

17. Wrighting, D.M.; Andrews, N.C. Interleukin-6 induces hepcidin expression through STAT3. Blood 2006, 108, 3204-3209. [CrossRef] [PubMed]

18. Xu, Y.X.; Du, F.; Jiang, L.R.; Gong, J.; Zhou, Y.F.; Luo, Q.Q.; Qian, Z.M.; Ke, K. Effects of aspirin on expression of iron transport and storage proteins in BV-2 microglial cells. Neurochem. Int. 2015, 91, 72-77. [CrossRef] [PubMed]

19. Casey, J.L.; Hentze, M.W.; Koeller, D.M.; Caughman, S.W.; Rouault, T.A.; Klausner, R.D.; Harford, J.B. Iron-responsiveelements: Regulatory RNA sequences that control mRNA levelsand translation. Science 1988, 240, 924-928. [CrossRef] [PubMed]

20. Klausner, R.D.; Rouault, T.; Harford, J.B. Regulating the fate of mRNA: The control of cellular iron metabolism. Cell 1993, 72, 19-28. [CrossRef]

21. Weiss, G.; Goossen, B.; Doppler, W.; Fuchs, D.; Pantopoulos, K.; Werner-Felmayer, G.; Wachter, H.; Hentze, M.W. Translationalregulation via iron responsive elements by the nitricoxide/NO-synthase pathway. EMBO J. 1993, 12, 3651-3657. [PubMed]

22. Wang, Q.; Du, F.; Qian, Z.M.; Ge, X.H.; Zhu, L.; Yung, W.H.; Yang, L.; Ke, Y. Lipopolysaccharide induces a significant increase in expression of iron regulatory hormone hepcidin in the cortex and substantianigra in rat brain. Endocrinology 2008, 149, 3920-3925. [CrossRef] [PubMed]

23. Qian, Z.M.; He, X.; Liang, T.; Wu, K.C.; Yan, Y.C.; Lu, L.N.; Yang, G.; Luo, Q.Q.; Yung, W.H.; Ke, Y. Lipopolysaccharides up regulate hepcidin expression in the neurons via microglia and the IL-6/STAT3 signaling pathway. Mol. Neurobiol. 2014, 50, 811-820. [CrossRef] [PubMed]

24. Kopp, E.; Ghosh, S. Inhibition of NF-кB by sodium salicylate and aspirin. Science 1994, 265, 956-969. [CrossRef] [PubMed]

25. Kawai, T.; Akira, S. Signaling to NF-кB by Toll-like receptors. Trends Mol. Med. 2007, 13, 460-469. [CrossRef] [PubMed] 
26. Grilli, M.; Pizzi, M.; Memo, M.; Spano, P. Neuroprotection by aspirin and sodium salicylate through blockade of NF- $k$ B activation. Science 1996, 274, 1383-1385. [CrossRef] [PubMed]

27. Yin, M.J.; Yamamoto, Y.; Gaynor, R.B. The anti-inflammatory agents aspirin and salicylate inhibit the activity of IкB kinase- $\beta$. Nature 1998, 396, 77-80. [PubMed]

28. Wu, S.; Zhang, K.; Lv, C.; Wang, H.; Cheng, B.; Jin, Y.; Chen, Q.; Lian, Q.; Fang, X. Nuclear Factor-kB mediated lipopolysaccharide-induced mRNA expression of hepcidin in human peripheral blood leukocytes. Innate Immun. 2012, 18, 318-324. [CrossRef] [PubMed]

29. Hayden, M.S.; West, A.P.; Ghosh, S. NF-kB and the immune response. Oncogene 2006, 25, 6758-6780. [CrossRef] [PubMed]

30. Kühn, L.C. Iron regulatory proteins and their role in controlling iron metabolism. Metallomics 2015, 7, 232-243. [CrossRef] [PubMed]

31. Anderson, C.P.; Shen, M.; Eisenstein, R.S.; Leibold, E.A. Mammalian iron metabolism and its control by iron regulatory proteins. Biochim. Biophys. Acta 2012, 1823, 1468-1483. [CrossRef] [PubMed]

32. Jana, N.R. NSAIDs and apoptosis. Cell. Mol. Life Sci. 2008, 65, 1295-1301. [CrossRef] [PubMed]

33. Warner, T.D.; Mitchell, J.A. Cyclooxygenases: New forms, new inhibitors, and lessons from the clinic. FASEB J. 2004, 18, 790-804. [CrossRef] [PubMed]

34. Williams, C.S.; Mann, M.; DuBois, R.N. The role of cyclooxygenases in inflammation, cancer, and development. Oncogene 1999, 18, 7908-7916. [CrossRef] [PubMed]

35. Ejima, K.; Layne, M.D.; Carvajal, I.M.; Kritek, P.A.; Baron, R.M.; Chen, Y.H.; vom Saal, J.; Levy, B.D.; Yet, S.F.; Perrella, M.A. Cyclooxygenase-2-deficient mice are resistant to endotoxin-induced inflammation and death. FASEB J. 2003, 17, 1325-1327. [CrossRef] [PubMed]

36. Dong, C.; Davis, R.J.; Flavell, R.A. MAP kinases in the immune response. Annu. Rev. Immunol. 2002, 20, 55-72. [CrossRef] [PubMed]

37. Takeda, K.; Akira, S. TLR signaling pathways. Semin. Immunol. 2004, 16, 3-9. [CrossRef] [PubMed]

38. Chuang, Y.F.; Yang, H.Y.; Ko, T.L.; Hsu, Y.F.; Sheu, J.R.; Ou, G.; Hsu, M.J. Valproic acid suppresses lipopolysaccharide-induced cyclooxygenase-2 expression via MKP-1 in murine brain microvascular endothelial cells. Biochem. Pharmacol. 2014, 88, 372-383. [CrossRef] [PubMed]

39. Jin, J.; Samuvel, D.J.; Zhang, X.; Li, Y.; Lu, Z.; Lopes-Virella, M.F.; Huang, Y. Coactivation of TLR4 and TLR2 / 6 coordinates an additive augmentation on IL-6 gene transcription via p38MAPK pathway in U937 mononuclear cells. Mol. Immunol. 2011, 49, 423-432. [CrossRef] [PubMed]

40. Hsu, Y.F.; Sheu, J.R.; Lin, C.H.; Chen, W.C.; Hsiao, G.; Ou, G.; Chiu, P.T.; Hsu, M.J. MAPK phosphatase-1 contributes to trichostatin A inhibition of cyclooxygenase-2 expression in human umbilical vascular endothelial cells exposed to lipopolysaccharide. Biochim. Biophys. Acta 2011, 1810, 1160-1169. [CrossRef] [PubMed]

41. Hsu, M.J.; Chang, C.K.; Chen, M.C.; Chen, B.C.; Ma, H.P.; Hong, C.Y.; Lin, C.H. Apoptosis signalregulating kinase 1 in peptidoglycan-induced COX-2 expression in macrophages. J. Leukoc. Biol. 2010, 87, 1069-1082. [CrossRef] [PubMed]

42. Turpeinen, T.; Nieminen, R.; Moilanen, E.; Korhonen, R. Mitogen-activated protein kinase phosphatase-1 negatively regulates the expression of interleukin-6, interleukin-8, and cyclooxygenase-2 in A549 human lung epithelial cells. J. Pharmacol. Exp. Ther. 2010, 333, 310-318. [CrossRef] [PubMed]

43. He, W.; Qian, Z.M.; Zhu, L.; Christopher, Q.; Du, F.; Yung, W.H.; Ke, Y. Ginkgolides mimic the effects of hypoxic preconditioning to protect $\mathrm{C} 6$ cells against ischemic injury by up-regulation of hypoxia-inducible factor-1 $\alpha$ and erythropoietin. Int. J. Biochem. Cell Biol. 2008, 40, 651-662. [CrossRef] [PubMed]

44. Kim, B.W.; Koppula, S.; Park, S.Y.; Hwang, J.W.; Park, P.J.; Lim, J.H. Attenuation of inflammatory-mediated neurotoxicity by Saururuschinensis extract in LPS-induced BV-2 microgliacells via regulation of NF- $\mathrm{kB}$ signaling and anti-oxidant properties. BMC Complement. Altern. Med. 2014, 14, 502. [CrossRef] [PubMed]

45. Du, F.; Qian, Z.M.; Luo, Q.; Yung, W.H.; Ke, Y. Hepcidin suppresses brain iron accumulation by downregulating iron transport proteins in iron-overloaded rats. Mol. Neurobiol. 2015, 52, 101-114. [CrossRef] [PubMed] 
46. Du, F.; Qian, Z.M.; Gong, Q.; Zhu, Z.J.; Lu, L.; Ke, Y. The iron regulatory hormone hepcidin inhibits expression of iron release as well as iron uptake proteins in J774 cells. J. Nutr. Biochem. 2012, 23, 1694-1700. [CrossRef] [PubMed]

47. Chang, Y.Z.; Qian, Z.M.; Wang, K.; Zhu, L.; Yang, X.D.; Du, J.R.; Jiang, L.; Ho, K.P.; Wang, Q.; Ke, Y. Effects of development and iron status on ceruloplasmin expression in rat brain. J. Cell. Physiol. 2005, 204, 623-633. [CrossRef] [PubMed]

48. Du, F.; Qian, C.; Qian, Z.M.; Wu, X.M.; Xie, H.; Yung, W.H.; Ke, Y. Hepcidin directly inhibits transferrin receptor 1 expression in astrocytes via a cyclic AMP-protein kinase A pathway. Glia 2011, 59, 936-945. [CrossRef] [PubMed]

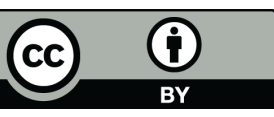

(C) 2016 by the authors; licensee MDPI, Basel, Switzerland. This article is an open access article distributed under the terms and conditions of the Creative Commons Attribution (CC-BY) license (http://creativecommons.org/licenses/by/4.0/). 